Elena G. Popkova ${ }^{1}$

Article info:

Received 20.11.2019

Accepted 25.02.2020

$\mathrm{UDC}-338.246 .83$

DOI - 10.24874/IJQR14.02-01

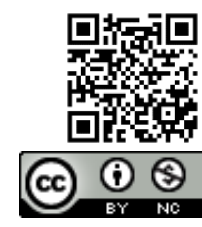

\section{A NEW TREATMENT OF QUALITY OF GOODS AND SERVICES IN THE CONDITIONS OF THE KNOWLEDGE ECONOMY: OPPOSITION OF TRADITIONS AND INNOVATIONS}

Abstract: The research aims at specifying the scientific treatment of quality of goods and services in the conditions of the knowledge economy through the prism of correlation of traditions and innovations. The paper contains a case study by the example of modern Russia - as one of the countries with the most developed knowledge economy. The author develops a new method of collection of factual data for determining the correlation of traditions and innovations during treatment of quality of goods and services in the knowledge economy by the example of modern Russia. The methodology of the research includes the regression analysis and factor analysis. As a result of the research, scientific treatment of quality of goods and services in the conditions of the knowledge economy is specified through the prism of correlation of traditions and innovations. It is determined that in modern Russia (2019) the consumers pay a lot of attention to the indicators of innovations during determination of quality of goods and services. Consumers' opinion is taken into account in modern Russia. Quality of the considered goods and services in 2019 grew, as compared to 2015, due to improvement of their innovative characteristics. Based on this, it is recommended - in the mid-term - to continue the set course of state and corporate management of quality of goods and services in Russia and to pay more attention to improvement of their innovative characteristics.

Keywords: Quality; Goods and services; Knowledge economy; Traditions; Innovations; Russia

\section{Introduction}

The knowledge economy has been proclaimed a modern type of the economic system in which the latest achievements of social mode and progressive technologies are implemented. Due to this, prominent economic results are achieved - of which the key one is unprecedented rate of economic growth. From the scientific and theoretical point of view (normative economics), the most preferable form of the knowledge economy is the one in which innovations dominate. An important argument in favor of this is multiple advantages of innovative development of economy, which include increasing and supporting the high level (in the long-term) of the global competitiveness of domestic goods and services and maximizing the effectiveness (efficiency and profitability) of production of goods and provision of services.

${ }^{1}$ Corresponding author: Elena G. Popkova

Email: elenapopkova@yahoo.com 
At the same time, from the practical point of view (descriptive economics), in view of the existing large differences in susceptibility of social systems to changes and their reaction to innovations, an obvious fact that the knowledge economy acquires various forms in the economic practice. Thus, the knowledge economy is peculiar for active struggle of traditions and innovations. A current and unsolved problem is scientific treatment of quality of goods and services in the conditions of the knowledge economy through the prism of correlation of traditions and innovations.

The universal formula of assessment of quality of goods and services in the conditions of the knowledge economy according to the criterion of evaluation of innovativeness (the more innovations, the better), which is offered by the normative economics, does not allow for high precision or correctness of the results of the assessment - as it reflects only the macro-economic position (advantages for the economic system on the whole) and does not take into account the micro-economic position (advantages for interested parties - primarily, consumers).

This paper aims at specifying the scientific treatment of quality of goods and services in the conditions of the knowledge economy through the prism of correlation of traditions and innovations. The work contains a case study by the example of modern Russia - as one of the countries with the most developed knowledge economy. This goal is achieved with the help of the following tasks:

- analysis of correlation of significance of traditions and innovations during formation of perceived quality of goods and services in the conditions of the knowledge economy;

- studying the dynamics of the change of quality of goods and services in the conditions of the knowledge economy depending on correlation of traditions and innovations.

\section{Literature review}

Two approaches to treatment of quality of goods and services in the conditions of the knowledge economy could be distinguished in the modern economic literature. The normative approach envisages emphasis on innovations and prioritization of the innovative components during assessment and maximization of quality of goods and services in the conditions of the knowledge economy. The representatives of this approach - e.g., Hussein et al. (2019) - note that knowledge management at companies of the hi-tech sector of economy should be based on innovations.

Nguyen (2018) notes the dependence of radical innovations on intellectual capital and lows of knowledge and the significance of innovations in the transit economy (shown by the example of Vietnam). Morisson \& Bevilacqua (2018) also confirm the large significance of innovations for formation and increase of quality of goods and services (shown by the example of Chattanooga's innovation district). Sazegar et al. (2018) comes to a conclusion that competitive advantages that are based on innovations have the highest priority and duration $\mathrm{n}$ the transit knowledge economy (shown by the example of Oman).

Tsakalerou (2018) notes that intellectual property is the key driver of success of business in the knowledge economy, as it largely determines the quality of products through the increase of its innovativeness. Degelsegger-Márquez et al. (2018) notes that regional knowledge economies should be based on the global innovative networks for supporting their effectiveness and competitiveness (shown by the example of Southeast Asia). Al-Mubaraki \& Busler (2017) substantiate that innovations are a tool of development of the knowledge economy and the key factor of quality of the manufactured goods and services - for they create new opportunities and cause new threats for modern companies. 
Khayati (2017) notes that innovations and scientific research fully determine the quality of goods and services in the conditions of the knowledge economy (shown by the example of GCC countries). Seddighi (2015) presents a model of innovative growth of a company in the knowledge economy and substantiates its advantage as compared to the model of traditional growth - due to higher quality of manufactured and sold goods and services. Khadir-Poggi \& Keating (2015) comes to a conclusion that intellectual capital, knowledge management, and innovations play the key role in the activities of small companies - as they determine the quality of products (shown by the example of Ireland).

Bicə et al. (2015) emphasizes the significance and necessity for innovations management in the knowledge economy due to their large influence on quality of goods and services. Petrenko et al. (2018) proves that only the foundation on innovations will allow the knowledge economy to preserve its sustainability. The important role of innovations in formation of quality of goods and services in the knowledge economy is noted in the works Popkova et al. (2018a), Popkova et al. (2018b), Popkova et al. (2017), Popkova et al. (2019), Popkova \& Sergi (2018), Popkova et al. (2018c), Vujović et al. 2017, etc.

The descriptive approach envisages refusal from versatility and determination of own (specific) treatment of goods and services in each separate knowledge economy (economic system). This approach is presented in Tatu et al. (2019) - the authors substantiate the correlation between managing intellectual property and managing quality of products in the modern knowledge economy with simultaneous emphasis on significance of traditions for ensuring stable and high quality of products. Roy \& Mitra (2018) notes that in the countries with developing market economy the knowledge management directly influences and largely determines the quality of products (shown by the example of state services).
Bucur (2017) writes that quality of products determines quality life - but it should not necessarily be based on innovations. Balcerzak \& Pietrzak (2016) writes that institutes in the knowledge economy determine the quality of goods and services; the correlation of traditions and innovations could be random (it depends on the specifics of the economic system). Wiedmann et al. (2012) emphasizes that quality of goods and services in the knowledge economy is determined by the context (shown by the example of urban economies). del Valle et al. (2011) states that quality of goods and services is a flexible category in the knowledge economy, which depends on a lot of various factors (shown by the example of Madrid).

Farooq et al. (2019) substantiate that in the age of transformation of marketing the quality of goods and services is blurred and is treated differently by different consumers depending on the influence of the company's marketing efforts on them (shown by the example of Malaysia). Cruz \& Mendes (2019) note that quality of goods and services depends on consumer behavior and consumer preferences - not on traditions and innovations of a company (shown by the example of Cape Verde'S Public Hospitals). Simat et al. (2018) states that consumer orientation determines the quality of goods and services (shown by the example of tourist services). Bazrkar et al. (2018) points out that there is a close interconnection between management of quality of goods and services and effectiveness of a company's activities and the key criterion of success of quality management is flexibility due to instability of the balance of traditions and innovations during its formation (shown by the example of bank services).

In this article, the author uses the descriptive approach, as it is very close to the economic reality and is preferable during empirical research. This article is to fill the gap in the descriptive approach, which consists in deficit of factual data. The representatives of 
this approach substantiated the necessity for applying different treatments to quality of goods and services in each knowledge economy, while the treatments are not presented due to insufficiency of statistical data for their development. That's why here a proprietary method of collection of factual data for determining the correlation of traditions and innovations during treatment of quality of goods and services in the knowledge economy by the example of modern Russia is developed.

\section{Materials and method}

This research is performed on the basis of top7 regions of Russia - according to the level of development of the knowledge economy. It covers two times periods: 2015 and 2019. The research is performed for three types of goods and services: retail trade (goods), high-tech products (goods), and state services (services). The two following hypothesis are offered and verified:

Hypothesis H1: in the course of development of the knowledge economy, the share of innovations grows (and the share of traditions reduces) in the treatment of quality of goods and services. In order to verify this hypothesis, a sociological survey of 3,500 consumers (500 people from each region) was conducted; it was aimed at determining two components of quality for each distinguished type of goods and services:

significance of various indicators of quality (by assigning weight coefficients which sum equals 1);

factual achievement of various indicators of quality (level of quality via point evaluation 1-10).

All distinguished indicators of quality of goods and services (universal for all types) are divided into two types: indicators of innovations (I) and indicators of traditions (T). This allows determining the correlation of significance of aggregate (calculated with the help of finding the sum for all indicators) indicators of innovations and indicators of traditions. For this, the regression analysis of the influence of traditions and innovations on perceived quality of various types of products in top-7 regions of Russia as to the level of development of the knowledge economy in 2019 is performed.

Expanded regression analysis is not required; it is sufficient to perform a comparative analysis of the regression coefficients (b) in the models of paired linear regression of the type $y=a+b^{*} x$ and coefficients of determination (R2). In the given equation, the dependent variable $(\mathrm{x}-$ common for all models) is the index of the knowledge economy in the region of Russia, and the independent variables (various for all models) are sums of the weights of traditions and innovations in the regions. The confirmation of hypothesis $\mathrm{H} 1$ is large values of regression coefficients and determination coefficients in the models of dependence of innovations on the index of the knowledge economy as compared to the models of dependence of traditions on the index of the knowledge economy.

Hypothesis H2: in top-7 regions of Russia as to the level of development of the knowledge economy, the consumers' opinion is fully accounted during formation of quality of goods and services. For this, the following integral indicators are calculated:

- $\quad$ trad: sum of the indicators of traditions;

- Qvltrad: sum of the weights of traditions;

- $\quad$ innov: sum of the indicators of innovations;

- Kvlinnov: sum of weights of innovations.

Based on these indicators, the factor analysis is performed - it is aimed at determining the growth of quality of goods and services by means of improvement of the indicators of innovations ( $\Delta$ Qua( $\sum$ innov)2019/2015) on average for all regions (direct average is calculated) in view of the distinguished types of goods and services, with the help of the following formula: 
$\Delta$ Qua $\left(\sum_{\text {innov }}\right) 2019 / 2015=\left(\sum_{\text {trad }} 2015 * \mathrm{Qvl}_{\text {trad }} 2\right.$ $\left.015+\sum_{\text {innov }} 2019 * Q^{2} l_{\text {innov }} 2015\right)-Q u a 2015$ (1)

Quality of goods and services in 2015 (Qua2015) is calculated with the following formula:

Qua2015 $==\sum_{\text {trad }} 015^{*} \mathrm{Qv1} \mathrm{l}_{\text {trad }} 2015+\sum_{\text {innov }} 2015$

$* \mathrm{Qvl}_{\text {innov }} 2015$

Quality of goods and services in 2019. (Qua2019) is calculated with the following formula:

Qua2019 $=\sum_{\text {trad }} 2019 * Q v_{\text {trad }} 2019+\sum_{\text {innov }} 2019$

*Qvl innov $_{\text {2019 }} 2019$

The conformation of hypothesis $\mathrm{H}_{2}$ is correspondence of consumer preferences $\left(\mathrm{Qvl} \mathrm{l}_{\text {innov }}\right)$ and growth of quality of goods and services by means of improvement of the indicators of innovations $\Delta$ Qua( $\left(\sum_{\text {innov }}\right) 2019 / 2015$.

\section{Results}

\subsection{Analysis of correlation of significance of traditions and innovations during formation of perceived quality of goods and services in the conditions of the knowledge economy}

As a result of the sociological survey, the following results were obtained - they reflect the significance of traditions and innovations and perceived quality of retail trade products (Table 1, Table 4 - see Appendix), hi-tech products (Table 2, Table 5 - see Appendix) and state services (Table 3, Table 6 - see Appendix) in top-7 regions of Russia as to the level of development of the knowledge economy in 2015 and in 2019.

Based on the data of Tables 1-6, we built Table 7 , in which the following legend is used:

- y11: sum of weight coefficients of indicators of traditions of perceived quality of retail trade products in the region in 2019;

- y12: sum of weight coefficients of indicators of innovations of perceived quality of retail trade products in the region in 2019;

- y21: sum of weight coefficients of indicators of traditions of perceived quality hi-tech products in the region in 2019;

- y22: sum of weight coefficients of indicators of innovations of perceived quality hi-tech products in the region in 2019;

- $y 31$ : sum of weight coefficients of indicators of traditions of perceived quality state services in the region in 2019;

- $y_{32}$ : sum of weight coefficients of indicators of innovations of perceived quality state services in the region in 2019.

Table 7. Data for the regression analysis of the influence of traditions and innovations on perceived quality of various types of products in top-7 regions of Russia as to the level of development of the knowledge economy in 2019.

\begin{tabular}{|c|c|c|c|c|c|c|c|}
\hline \multirow{2}{*}{ Region } & \multirow{2}{*}{$\mathbf{x}$} & \multicolumn{2}{|c|}{$\begin{array}{c}\text { Retail trade } \\
\text { products }\end{array}$} & \multicolumn{2}{c|}{ Hi-tech products } & \multicolumn{2}{c|}{ State services } \\
\cline { 3 - 8 } & & $\mathbf{y}$ & $\mathbf{y 1 2}$ & $\mathbf{y 2 1}$ & $\mathbf{y} 22$ & $\mathbf{y 3 1}$ & $\mathbf{y 3 2}$ \\
\hline Republic of Tatarstan & 0.67 & 0.43 & 0.57 & 0.37 & 0.63 & 0.51 & 0.49 \\
\hline Tomsk Oblast & 0.63 & 0.49 & 0.51 & 0.48 & 0.52 & 0.37 & 0.63 \\
\hline Moscow Oblast & 0.60 & 0.51 & 0.49 & 0.46 & 0.54 & 0.5 & 0.5 \\
\hline Novosibirsk Oblast & 0.58 & 0.36 & 0.64 & 0.34 & 0.66 & 0.42 & 0.58 \\
\hline Kaluga Oblast & 0.57 & 0.44 & 0.56 & 0.48 & 0.52 & 0.31 & 0.69 \\
\hline Nizhny Novgorod Oblas & 0.55 & 0.38 & 0.62 & 0.41 & 0.59 & 0.51 & 0.49 \\
\hline Ulyanovsk Oblast & 0.54 & 0.47 & 0.53 & 0.56 & 0.44 & 0.44 & 0.56 \\
\hline
\end{tabular}

Source: developed and compiled by the author based on Association of innovative regions of Russia (2019) 
As a result of the regression analysis of data from Table 7 the following results were obtained:

- $\quad$ increase of the index of development of the knowledge economy by 0.1 points leads to increase of the sum of weight coefficients of indicators of traditions of perceived quality of retail trade products by 0.2838 $\left(\mathrm{y}_{11}=0.2722+0.2838 * \mathrm{x}\right)$, correlation of indicators $-5.55 \%$ : $\left(\mathrm{R}^{2}=0.0555\right)$;

- increase of the index of development of the knowledge economy by 0.1 point leads to decrease of the sum of weight coefficients of indicators of innovations of perceived quality of retail trade products by 0.2838 $\left(\mathrm{y}_{12}=0.7228-0.2838 * \mathrm{x}\right)$, correlation of indicators $-5.55 \%$ : $\left(\mathrm{R}^{2}=0.0555\right)$;

- Increase of the index of development of the knowledge economy by 0.1 points leads to decrease of the sum of weight coefficients of indicators of traditions of perceived quality of hitech products by 0.6644 $\left(\mathrm{y}_{12}=0.8358-0.6644 \mathrm{x}\right)$, correlation of indicators $-1.66 \%$ : $\left(\mathrm{R}^{2}=0.166\right)$;

- increase of the index of development of the knowledge economy by 0.1 points leads to increase of the sum of weight coefficients of indicators of innovations of perceived quality of hi-tech products by 0.6644 $\left(\mathrm{y}_{22}=0.1642+0.6644 \mathrm{x}\right)$, correlation of indicators $-1.66 \%$ : $\left(\mathrm{R}^{2}=0.166\right)$;

- increase of the index of development of the knowledge economy by 0.1 points leads to increase of the sum of weight coefficients of indicators of traditions of perceived quality of state services by 0,2703 $\left(\mathrm{y}_{31}=0.2773+0.2703 \mathrm{x}\right), \quad$ correlation of indicators $-2.61 \%$ : $\left(\mathrm{R}^{2}=0.0261\right)$;

- increase of the index of development of the knowledge economy by 0.1 points leads to decrease of the sum of weight coefficients of indicators of innovations of perceived quality of state services by $0.2703\left(\mathrm{y}_{32}=0.7227\right.$ $0.2703 \mathrm{x}$ ), correlation of indicators $2.61 \%$ : $\left(\mathrm{R}^{2}=0.0261\right)$.

Thus, the offered hypothesis $\mathrm{H}_{1}$ has been proved - on average, coefficients of regression (b) in the models of dependence of indicators of innovations on the index of development of the knowledge economy are higher (on average: 0.1103) than in the models of dependencies of the indicators of traditions on the index of development of the knowledge economy (on average: -0.1103). Determination coefficients $\left(\mathrm{R}^{2}\right)$ are equal in the models of traditions and innovations in view of each type of goods and services, which emphasizes the insignificance of the differences. At the same time, it is necessary to note that in two of the three studied types of goods and services (retail trade products and state services) the indicators of traditions reduce in the course of development of the knowledge economy, and the indicators of innovations grow - which also confirms the offered hypothesis.

\subsection{Studying the dynamics of change of quality of goods and services in the conditions of the knowledge economy depending on the correlation of traditions and innovations}

For studying the dynamics of change of quality of goods and services in the conditions of the knowledge economy depending on the correlation of traditions and innovations, Tables $8-10$ were built and the factor analysis was performed.

Based on the data of Table 8, the factor analysis of the influence of traditions and innovations on the factual quality of retail trade products in top-7 regions of Russia as to the level of development of the knowledge economy in 2015 and 2019 was performed.

Thus:

- Qua2015=43.09*0.45+36.98*0.55= 39.72 points;

- Qua2019=43.50*0.44+37.31*0.56= 40.03 points; 
- $\quad \Delta$ Qua $\left(\sum_{\text {innov }}\right) 2019 / 2015=(43.09 * 0.4$ $5+37.31 * 0.55)$-Qua2015=39.90$39.72=0.18$ points.

Therefore, quality of retail trade products in 2019 (39.72 points), as compared to 2015 (40.03 points), grew by 0.31 points (40.03-
39.72). Growth of quality of retail trade products by means of improvement of the indicators of innovations $\left(\Delta\right.$ Qua $\left.\left(\sum_{\text {innov }}\right) 2019 / 2015\right)$ on average for all regions constituted 0.18 points - i.e., $58.99 \%$ of aggregate growth $(0.18 * 100 \% / 0.31)$.

Table 8. Data for the factor analysis of influence of traditions and innovations on the factual quality of retail trade products in top-7 regions of Russia as to the level of development of the knowledge economy in 2015 and 2019. (the table developed and compiled by the author)

\begin{tabular}{|c|c|c|c|c|c|c|c|c|}
\hline \multirow{2}{*}{ Region } & \multicolumn{4}{|c|}{$\mathbf{2 0 1 5}$} & \multicolumn{4}{|c|}{$\mathbf{2 0 1 9}$} \\
\cline { 2 - 9 } & $\sum_{\text {trad }}$ & $\mathbf{Q v l}_{\text {trad }}$ & $\sum_{\text {innov }}$ & $\mathbf{Q v l}_{\text {innov }}$ & $\sum_{\text {trad }}$ & $\mathbf{Q v l}_{\text {trad }}$ & $\sum_{\text {innov }}$ & Qvlinnov \\
\hline Republic of Tatarstap & 36.43 & 0.43 & 38.06 & 0.57 & 36.78 & 0.43 & 38.43 & 0.57 \\
\hline Tomsk Oblast & 48.55 & 0.5 & 35.75 & 0.5 & 48.96 & 0.49 & 36.19 & 0.51 \\
\hline Moscow Oblast & 52.33 & 0.52 & 40.09 & 0.48 & 52.78 & 0.51 & 40.31 & 0.49 \\
\hline Novosibirsk Oblast & 38.73 & 0.37 & 33.87 & 0.63 & 39.16 & 0.36 & 34.19 & 0.64 \\
\hline Kaluga Oblast & 39.45 & 0.44 & 42.47 & 0.56 & 39.83 & 0.44 & 42.76 & 0.56 \\
\hline $\begin{array}{c}\text { Nizhny Novgorod } \\
\text { Oblast }\end{array}$ & 29.63 & 0.39 & 34.97 & 0.61 & 30.02 & 0.38 & 35.38 & 0.62 \\
\hline Ulyanovsk Oblast & 56.54 & 0.49 & 33.63 & 0.51 & 56.94 & 0.47 & 33.9 & 0.53 \\
\hline On average & 43.09 & 0.45 & 36.98 & 0.55 & 43.50 & 0.44 & 37.31 & 0.56 \\
\hline
\end{tabular}

Table 9. Data for factor analysis of the influence of traditions and innovations on the factual quality of hi-tech products in top-7 regions of Russia as to the level of development of the knowledge economy in 2015 and 2019. (the table developed and compiled by the author)

\begin{tabular}{|c|c|c|c|c|c|c|c|c|}
\hline \multirow{2}{*}{ Region } & \multicolumn{4}{|c|}{2015} & \multicolumn{4}{|c|}{2019} \\
\cline { 2 - 9 } & $\sum_{\text {trad }}$ & $\mathrm{Qvl}_{\text {trad }}$ & $\sum_{\text {innov }}$ & $\mathrm{Qvl}_{\text {innov }}$ & $\sum_{\text {trad }}$ & $\mathrm{Qv}_{\text {trad }}$ & $\sum_{\text {innov }}$ & Qvlinnov \\
\hline Republic of Tatarstar & 31.88 & 0.39 & 40.89 & 0.61 & 32.29 & 0.37 & 41.33 & 0.63 \\
\hline Tomsk Oblast & 46.52 & 0.48 & 34.75 & 0.52 & 46.99 & 0.48 & 35.04 & 0.52 \\
\hline Moscow Oblast & 45.72 & 0.47 & 26.76 & 0.53 & 46.23 & 0.46 & 27.2 & 0.54 \\
\hline Novosibirsk Oblast & 36.54 & 0.38 & 43.28 & 0.62 & 36.96 & 0.34 & 43.68 & 0.66 \\
\hline Kaluga Oblast & 22.08 & 0.48 & 44.98 & 0.52 & 22.61 & 0.48 & 45.26 & 0.52 \\
\hline $\begin{array}{c}\text { Nizhny Novgorod } \\
\text { Oblast }\end{array}$ & 35.6 & 0.42 & 37.54 & 0.58 & 36.1 & 0.41 & 37.98 & 0.59 \\
\hline Ulyanovsk Oblast & 54.56 & 0.56 & 51.44 & 0.44 & 55.08 & 0.56 & 51.76 & 0.44 \\
\hline On average & 38.99 & 0.45 & 39.95 & 0.55 & 39.47 & 0.44 & 40.32 & 0.56 \\
\hline
\end{tabular}

Based on the data of Table 8 the factor analysis of the influence of traditions and innovations on the factual quality of hi-tech products in top-7 regions of Russia as to the level of development of the knowledge economy in 2015 and 2019 was performed in the following way:

- Qua2015=38.99*0.45+39.95*0.55= 39.51 points;

- Qua2019=39.47*0.44+40.32*0.56= 39.94 points;
- $\quad \Delta$ Qua $\left(\sum_{\text {innov }}\right) 2019 / 2015=(38.99 * 0.4$ $5+40.32 * 0.55)$-Qua2015=39.71$39.51=0.20$ points.

Therefore, quality of hi-tech products in 2019 (39.94 points), as compared to 2015 (39.51 points) grew by 0.43 points (39.94-39.51). Growth of quality of hi-tech products by means of improvement of the indicators of innovations ( $\Delta$ Qua $\left.\left(\sum_{\text {innov }}\right) 2019 / 2015\right)$ on average for all regions constituted 0.20 points - i.e., $47.18 \%$ of aggregate growth $(0.20 * 100 \% / 0.43)$. 
Table 10. Data for the factor analysis of the influence of traditions and innovations on the factual quality of state services in top-7 regions of Russia as to the level of development of the knowledge economy in 2015 and 2019. (the table developed and compiled by the author)

\begin{tabular}{|c|c|c|c|c|c|c|c|c|}
\hline \multirow{2}{*}{ Region } & \multicolumn{4}{|c|}{2015} & \multicolumn{4}{c|}{2019} \\
\cline { 2 - 9 } & $\sum_{\text {trad }}$ & Qvl trad & $\sum_{\text {innov }}$ & Qvlinnov & $\sum_{\text {trad }}$ & Qvl trad & $\sum_{\text {innov }}$ & Qvl linnov \\
\hline Republic of Tatarstar & 35.07 & 0.52 & 48.27 & 0.48 & 35.55 & 0.51 & 48.7 & 0.49 \\
\hline Tomsk Oblast & 60.82 & 0.38 & 29.51 & 0.62 & 61.16 & 0.37 & 29.87 & 0.63 \\
\hline Moscow Oblast & 43.53 & 0.54 & 34.88 & 0.46 & 44.04 & 0.5 & 35.28 & 0.5 \\
\hline Novosibirsk Oblast & 36.31 & 0.42 & 35.05 & 0.58 & 36.83 & 0.42 & 35.51 & 0.58 \\
\hline Kaluga Oblast & 46.95 & 0.32 & 26.86 & 0.68 & 47.5 & 0.31 & 27.27 & 0.69 \\
\hline $\begin{array}{c}\text { Nizhny Novgorod } \\
\text { Oblast }\end{array}$ & 54.23 & 0.51 & 31.6 & 0.49 & 54.61 & 0.51 & 31.95 & 0.49 \\
\hline Ulyanovsk Oblast & 42.35 & 0.46 & 40.39 & 0.54 & 42.83 & 0.44 & 40.87 & 0.56 \\
\hline On average & 45.61 & 0.45 & 35.22 & 0.55 & 46.07 & 0.44 & 35.64 & 0.56 \\
\hline
\end{tabular}

Based on the data of Table 8 , the factor analysis of the influence of traditions and innovations on the factual quality of state services in top-7 regions of Russia as to the level of development of the knowledge economy in 2015 and 2019 was performed in the following way:

- Qua2015=45.61*0.45+35.22*0.55= 39.90 points;

- Qua2019=46.07*0.44+35.64*0.56= 40.20 points;

- $\quad \Delta \mathrm{Qua}\left(\sum_{\text {innov }}\right) 2019 / 2015=(45.61 * 0.4$ $5+35.64 * 0.55)$-Qua2015=40.12$39.90=0.23$ points.

Therefore, quality of state services in 2019 . (39.90 points), as compared to 2015 (40.20 points), grew by 0.30 points (40.20-39.90). Growth of quality of state services by means of improvement of the indicators of innovations $\left(\Delta\right.$ Qua $\left.\left(\sum_{\text {innov }}\right) 2019 / 2015\right)$ on average for all regions constituted 0.23 points - i.e., $75.08 \%$ of aggregate growth $(0.23 * 100 \% / 0.30)$.

Thus, hypothesis $\mathrm{H}_{2}$ has been proved; it has been shown that consumers' opinion is taken into account during formation of quality of goods and services. In all studied types of products, weight indicators of innovations dominate - which emphasize their preferred character during determining the quality of goods and services. The average weight of the indicator of innovations for all studied types of goods and services in 2019 (Qvl $\left.\mathrm{l}_{\text {innov }}\right)$ constituted 0.56 . Growth of quality of retail trade products takes place mainly by means of improvement of the indicators of innovations $\Delta$ Qua $\left(\sum_{\text {innov }}\right) 2019 / 2015$ constituted 0.18 points $58.99 \%$ of aggregate growth of quality), hi-tech products - 0.20 points (47.18\% of aggregate growth of quality), state services -0.23 points $(75.08 \%$ of aggregate growth of quality).

\section{Conclusion}

Thus, as a result of the research, the scientific treatment of quality of goods and services in the conditions of the knowledge economy through the prism of correlation of traditions and innovations has been specified. It has been determined that during determination of quality of goods and services in modern Russia (2019) the consumers pay attention to the indicators of innovations. For retail trade products, the most important indicators are Possibility of receiving products at home and Absence of lines (online trade; for hi-tech products - Modern nature of products and its individuality; for state services - Absence of lines, possibility to file a request and obtain services any time, as well as simplicity of feedback (e-government).

Though values of all indicators in different regions of Russia are different, the common Russian trend is clear, and the differences are minimal. It is determined that in the course of development of the knowledge economy significance of the innovative component of 
quality of goods and services for consumers grows. Opinion of consumers is taken into account in modern Russia, and quality of the studied goods and services grew in 2019 as compared to 2015, mainly due to improvement of their innovative characteristics. Based on this, it is offered to continue the set course of state and corporate management of quality of goods and services in Russia in the mid-term and pay more attention to improvement of their innovative characteristics.

Acknowledgment: The research was performed with financial support from the Russian Fund of Fundamental Research within the scientific project No. 18-01000103 A.

\section{References:}

Al-Mubaraki, H. M., \& Busler, M. (2017). Challenges and opportunities of innovation and incubators as a tool for knowledge-based economy. Journal of Innovation and Entrepreneurship, 2(1), 14-28.

Association of innovative regions of Russia (2019). Rating of innovative regions in Russia. Retrieved on 26.07.2019 from: http://www.i-regions.org/reiting/rejting-innovatsionnogorazvitiya

Balcerzak, A. P., \& Pietrzak, M. B. (2016). Quality of institutions for knowledge-based economy within new institutional economics framework. Multiple criteria decision analysis for European countries in the years 2000-2013. Economics and Sociology, 9(4), 66-81.

Bazrkar, A., Milani, S. M., \& Nasab, S. A. (2018). The relationship between management commitment to service quality and organizational outputs considering the mediating role of effective participation of employees in banking services. International Journal for Quality Research, 12(3), 625-638.

Bicə, G., Constantinescu, M., \& Bicə, E. (2015). Innovation and knowledge management in a knowledge-based economy. World Review of Entrepreneurship, Management and Sustainable Development, 11(2-3), 156-171.

Bucur, A. (2017). How can we apply the models of the quality of life and the quality of life management in an economy based on knowledge? Economic Research-Ekonomska Istrazivanja, 30(1), 629-646.

Cruz, V., \& Mendes, L. (2019). The influence of service quality on users' behavioural intentions in developing countries: A cross-sectional study in Cape Verde'S Public Hospitals. International Journal for Quality Research, 13(2), 361-380.

Degelsegger-Márquez, A., Remøe, S. O., \& Trienes, R. (2018). Regional knowledge economies and global innovation networks - the case of Southeast Asia. Journal of Science and Technology Policy Management, 9(1), \66-86.

del Valle, R. M. G., Arjona, J. T., \& Aragón, L. D. A. (2011). Knowledge economy and quality of work in the metropolitan region of Madrid: A critical perspective. Scripta Nova, 2(1), 37 48.

Farooq, M., Khalil-Ur-Rehman, F., Tijjani, A. D., Younas, W., Sajjad, S., \& Zreen, A. (2019). Service quality analysis of private universities libraries in Malaysia in the era of transformative marketing. International Journal for Quality Research, 13(2), 269-284.

Hussein, A. S., Rosita, N. H., \& Ayuni, R. F. (2019). Knowledge management orientation behaviour and innovation: A lesson from Indonesia creative economy sector. International Journal of Sociotechnology and Knowledge Development, 11(1), 17-28. 
Khadir-Poggi, Y., \& Keating, M. (2015). Intellectual capital, knowledge management, knowledge economies and innovation: The case of small asset management firms in Ireland. International Journal of Knowledge and Learning, 10(2), 147-163.

Khayati, A. (2017). Innovation and scientific research in the context of knowledge economy: The case of GCC countries. International Journal of Economic Research, 14(9), 77-87.

Morisson, A., \& Bevilacqua, C. (2018). Balancing gentrification in the knowledge economy: the case of Chattanooga's innovation district. Urban Research and Practice, 1(1), 1-21.

Nguyen, D. Q. (2018). The impact of intellectual capital and knowledge flows on incremental and radical innovation: Empirical findings from a transition economy of Vietnam. Asia-Pacific Journal of Business Administration, 10(2-3), 149-170.

Petrenko, E., Pritvorova, T., \& Dzhazykbaeva, B. (2018). Sustainable developmett processes: Service sector in post-industrial economy. Journal of Security and Sustainability Issues, 7(4), 781-791. doi: https://doi.org/10.9770/jssi.2018.7.4(14).

Popkova, E., Gornostaeva, Z., \& Tregulova, N. (2018a). Role of innovations in provision of competitiveness and innovational development of economy and overcoming of "underdevelopment whirlpools" in Russia and countries of Eastern Europe. Journal of entrepreneurship in emerging economies, 10(3), 511-523.

Popkova, E. G., \& Sergi, B. S. (2018). Will Industry 4.0 and Other Innovations Impact Russia's Development? In Bruno S. Sergi (Ed.) Exploring the Future of Russia's Economy and Markets: Towards Sustainable Economic Development. Bingley, UK: Emerald Publishing Limited (pp. 51-68).

Popkova, E. G., Grechenkova, O. Yu, \& Boris, O. A. (2019). The prospects of using social marketing in economic criminology in the conditions of an emerging innovative economy. Russian journal of criminology, 11(2), 280-288.

Popkova, E. G., Poluyufta, L., \& Beshanova, Y. (2017). Innovations as a Basis for Marketing Strategies of Russian Oil Companies in the Conditions of Oil Prices Reduction. Conference on Overcoming Uncertainty of Institutional Environment as a Tool of Global Crisis Management. Contributions to Economics, 449-455.

Popkova, E. G., Popova, E. V., \& Sergi, B. S. (2018c). Clusters and Innovational Networks Toward Sustainable Growth. In Bruno S. Sergi (Ed.) Exploring the Future of Russia's Economy and Markets: Towards Sustainable Economic Development. Bingley, UK: Emerald Publishing Limited (pp. 107-124).

Popkova, E. G., Sozinova, A. A., \& Grechenkov, O. Yu. (2018b). Deficiencies in the legislative support of innovative activities in contemporary Russia and ways of addressing them. Russian journal of criminology, 12(4), 515-524.

Roy, S., \& Mitra, J. (2018). Tacit and explicit knowledge management and assessment of quality performance of public R\&D in emerging economies: An Indian perspective. Journal of Organizational Change Management, 31(1), 188-214.

Sazegar, M., Forouharfar, A., Hill, V., \& Faghih, N. (2018). The innovation-based competitive advantage in Oman's transition to a knowledge-based economy: Dynamics of innovation for promotion of entrepreneurship. Contributions to Management Science, 1(1), 491-518.

Seddighi, H. R. (2015). A model of a firm's innovation and growth in a knowledge-based economy. Journal of the Knowledge Economy, 6(2), 215-227. 
Simat, K., Blešić, I., Božić, S., Avramović, M., \& Ivkov, M. (2018). Customer orientation of employees in travel agencies as a predisposition of service quality: Test of Cose consequences model. International Journal for Quality Research, 12(4), 851-868.

Tatu, M. A., Pop, A. B., \& Tatu, S. (2019). The correlation between intellectual property management and quality management in the modern knowledge-based economy. Proceedings of the 10th International Conference on Electronics, Computers and Artificial Intelligence, ECAI 2018, 8679033.

Tsakalerou, M. (2018). Intellectual property as a key driver of business performance: The case of Singapore and its implications for innovation in a knowledge-based economy. International Journal of Learning and Intellectual Capital, 15(1), 83-92.

Vujović, A., Šaković Jovanović, J., Krivokapić, Z., Peković, S., Soković, M., \& Kramar, D. (2017). The relationship between innovations and quality management system. Tehnicki Vjesnik, 24(2), 551-556.

Wiedmann, F., Salama, A. M., \& Thierstein, A. (2012). A framework for investigating urban qualities in emerging knowledge economies: The case of Doha. Archnet-IJAR, 6(1), 42-56.

\section{Elena G. Popkova}

MGIMO University,

Moscow,

Russian Federation

elenapopkova@yahoo.com 


\section{Appendix}

Table 1. Significance of traditions and innovations and perceived quality of retail trade productsin top-7 regions of Russia as to the level of development of the knowledge economy in 2019.

\begin{tabular}{|c|c|c|c|c|c|c|c|c|c|c|c|c|c|c|c|c|}
\hline \multirow{2}{*}{ 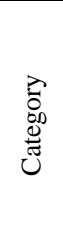 } & \multirow[b]{2}{*}{ Indicators } & \multirow[b]{2}{*}{ Type } & \multicolumn{2}{|c|}{$\begin{array}{l}\text { Republic } \\
\text { of } \\
\text { Tatarstan } \\
\end{array}$} & \multicolumn{2}{|c|}{$\begin{array}{l}\text { Tomsk } \\
\text { Oblast }\end{array}$} & \multicolumn{2}{|c|}{$\begin{array}{c}\text { Moscow } \\
\text { Oblast }\end{array}$} & \multicolumn{2}{|c|}{$\begin{array}{c}\text { Novosibirsk } \\
\text { Oblast }\end{array}$} & \multicolumn{2}{|c|}{$\begin{array}{l}\text { Kaluga } \\
\text { Oblast }\end{array}$} & \multicolumn{2}{|c|}{$\begin{array}{c}\text { Nizhny } \\
\text { Novgorod } \\
\text { Oblast } \\
\end{array}$} & \multicolumn{2}{|c|}{$\begin{array}{c}\text { Ulyanovsk } \\
\text { Oblast }\end{array}$} \\
\hline & & & $\begin{array}{l}0 \\
\frac{0}{00} \\
\frac{00}{20} \\
3\end{array}$ & 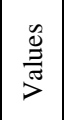 & $\begin{array}{l}0 \\
\frac{0}{0} \\
\frac{00}{0} \\
3 \\
3\end{array}$ & 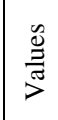 & $\begin{array}{l}\stackrel{n}{E} \\
.00 \\
\overrightarrow{3}\end{array}$ & 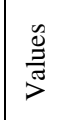 & $\begin{array}{l}\frac{\infty}{2} \\
\frac{000}{0} \\
3\end{array}$ & $\frac{\mathscr{Q}}{\stackrel{\sigma}{\sigma}}$ & $\begin{array}{l}0 \\
\frac{0}{00} \\
\frac{00}{0} \\
3\end{array}$ & $\frac{\mathscr{n}}{\stackrel{\varpi}{\pi}}$ & 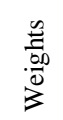 & $\frac{\mathscr{Q}}{\frac{\mathscr{V}}{\pi}}$ & $\begin{array}{l}0 \\
\frac{0}{00} \\
00 \\
30\end{array}$ & 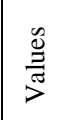 \\
\hline \multirow{4}{*}{ 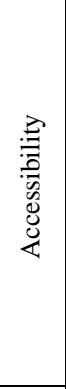 } & $\begin{array}{l}\text { Possibility of receiving } \\
\text { products at home }\end{array}$ & I & 0.13 & 6.2 & 0.07 & 7.98 & 0.1 & 8.69 & 0.25 & 1.65 & 0.11 & 4.15 & 0.23 & 3.48 & 0.12 & 6.66 \\
\hline & Absence of lines & I & 0.17 & 2.97 & 0.1 & 3.52 & 0.08 & 1.77 & 0.19 & 7.01 & 0.16 & 6.67 & 0.18 & 2.37 & 0.11 & 9.73 \\
\hline & $\begin{array}{l}\text { Absence of the necessity } \\
\text { for special equipment } \\
\text { and skills }\end{array}$ & $\mathrm{T}$ & 0.1 & 6.48 & 0.06 & 2.79 & 0.09 & 7.25 & 0.03 & 9.12 & 0.02 & 5.47 & 0.04 & 2.71 & 0.04 & 7.62 \\
\hline & \begin{tabular}{|c|} 
Stability, reliability, and \\
security (absence of \\
interruptions in products \\
supply)
\end{tabular} & $\mathrm{T}$ & 0.06 & 8.1 & 0.02 & 9.24 & 0.04 & 4.26 & 0.07 & 1.41 & 0.09 & 6.71 & 0.02 & 1.38 & 0.09 & 8.74 \\
\hline \multirow{2}{*}{ 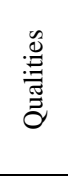 } & $\begin{array}{c}\text { Stability of the process of } \\
\text { purchase and usage of } \\
\text { products }\end{array}$ & $\mathrm{T}$ & 0.03 & 2.5 & 0.07 & 4.68 & 0.08 & 7.95 & 0.04 & 6.85 & 0.06 & 8.77 & 0.04 & 4.48 & 0.02 & 3.86 \\
\hline & $\begin{array}{l}\text { Modern nature of } \\
\text { products }\end{array}$ & I & 0.02 & 1.87 & 0.06 & 6.26 & 0.02 & 3.94 & 0.09 & 7.32 & 0.05 & 5.26 & 0.01 & 7.26 & 0.07 & 1.24 \\
\hline \multirow{3}{*}{ 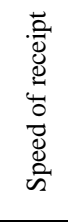 } & $\begin{array}{l}\text { Possibility of obtaining } \\
\text { products at once }\end{array}$ & $\mathrm{T}$ & 0.09 & 5.2 & 0.05 & 3.69 & 0.09 & 9.99 & 0.01 & 1.75 & 0.05 & 3.43 & 0.07 & 5.93 & 0.05 & 8.73 \\
\hline & $\begin{array}{l}\text { Personal contact with } \\
\text { supplier of products }\end{array}$ & $\mathrm{T}$ & 0.04 & 2.28 & 0.09 & 9.45 & 0.03 & 7.22 & 0.02 & 2.46 & 0.04 & 1.12 & 0.03 & 1.76 & 0.06 & 7.62 \\
\hline & $\begin{array}{l}\text { Possibility of applying } \\
\text { for products any time }\end{array}$ & I & 0.05 & 9.46 & 0.08 & 6.53 & 0.07 & 7.08 & 0.02 & 6.41 & 0.06 & 3.31 & 0.04 & 9.4 & 0.05 & 1.41 \\
\hline \multirow{2}{*}{ 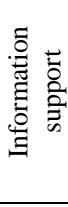 } & $\begin{array}{c}\text { Simplicity of selection of } \\
\text { the necessary products }\end{array}$ & $\mathrm{T}$ & 0.01 & 2.87 & 0.04 & 8.05 & 0.09 & 6.4 & 0.03 & 2.13 & 0.02 & 4.4 & 0.08 & 3.39 & 0.07 & 8.52 \\
\hline & $\begin{array}{c}\text { Informing on the process } \\
\text { of manufacture and } \\
\text { shipment of product } \\
\text { (provision of service) }\end{array}$ & I & 0.05 & 5.17 & 0.05 & 8.12 & 0.08 & 1.15 & 0.03 & 1.49 & 0.1 & 9.66 & 0.07 & 3.52 & 0.08 & 3.3 \\
\hline \multirow{2}{*}{ : } & $\begin{array}{l}\text { Individualization of } \\
\text { products }\end{array}$ & I & 0.1 & 8.83 & 0.08 & 1.11 & 0.07 & 9.04 & 0.05 & 1.76 & 0.07 & 9.24 & 0.06 & 8.27 & 0.04 & 3.21 \\
\hline & $\begin{array}{l}\text { Value of personal } \\
\text { relations with products } \\
\text { supplier }\end{array}$ & $\mathrm{T}$ & 0.03 & 3.94 & 0.09 & 9.16 & 0.01 & 6.69 & 0.08 & 9.48 & 0.09 & 3.58 & 0.08 & 6.72 & 0.1 & 4.76 \\
\hline \multirow{2}{*}{ 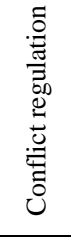 } & $\begin{array}{c}\text { Simplicity of feedback } \\
\text { (reviews, complaints, and } \\
\text { offers) }\end{array}$ & I & 0.05 & 3.93 & 0.07 & 2.67 & 0.07 & 8.64 & 0.01 & 8.55 & 0.01 & 4.47 & 0.03 & 1.08 & 0.06 & 8.35 \\
\hline & $\begin{array}{c}\text { Simplicity and speed of } \\
\text { protection and sales legal } \\
\text { rights for return and } \\
\text { exchange of products }\end{array}$ & $\mathrm{T}$ & 0.07 & 5.41 & 0.07 & 1.9 & 0.08 & 3.02 & 0.08 & 5.96 & 0.07 & 6.35 & 0.02 & 3.65 & 0.04 & 7.09 \\
\hline
\end{tabular}

Source: data obtained by the author, the table developed and compiled by the author. 
Table 2. Significance of traditions and innovations and perceived quality of hi-tech products in top-7 regions of Russia as to the level of development of the knowledge economy in 2019

\begin{tabular}{|c|c|c|c|c|c|c|c|c|c|c|c|c|c|c|c|c|}
\hline \multirow{2}{*}{ 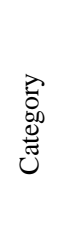 } & \multirow[b]{2}{*}{ Indicators } & \multirow[b]{2}{*}{ Type } & \multicolumn{2}{|c|}{$\begin{array}{l}\text { Republic } \\
\text { of } \\
\text { Tatarstan }\end{array}$} & \multicolumn{2}{|c|}{$\begin{array}{l}\text { Tomsk } \\
\text { Oblast }\end{array}$} & \multicolumn{2}{|c|}{$\begin{array}{l}\text { Moscow } \\
\text { Oblast }\end{array}$} & \multicolumn{2}{|c|}{$\begin{array}{c}\text { Novosibirsk } \\
\text { Oblast }\end{array}$} & \multicolumn{2}{|c|}{$\begin{array}{l}\text { Kaluga } \\
\text { Oblast }\end{array}$} & \multicolumn{2}{|c|}{$\begin{array}{c}\text { Nizhny } \\
\text { Novgorod } \\
\text { Oblast }\end{array}$} & \multicolumn{2}{|c|}{$\begin{array}{c}\text { Ulyanovsk } \\
\text { Oblast }\end{array}$} \\
\hline & & & $\begin{array}{l}\frac{0}{0} \\
\frac{00}{0} \\
3 \\
3\end{array}$ & 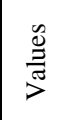 & $\begin{array}{l}0 \\
\frac{0}{60} \\
.00 \\
30\end{array}$ & $\frac{\mathscr{2}}{\stackrel{\pi}{\pi}}$ & $\begin{array}{l}0 \\
\frac{0}{60} \\
\frac{.00}{0} \\
3\end{array}$ & 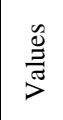 & $\begin{array}{l}\frac{\infty}{E} \\
\frac{000}{2} \\
3\end{array}$ & $\frac{\mathscr{y}}{\stackrel{\varpi}{\pi}}$ & $\frac{0}{3}$ & $\underset{\frac{0}{\Xi}}{\frac{0}{\pi}}$ & $\begin{array}{l}\frac{n}{0} \\
\frac{000}{2} \\
3\end{array}$ & $\frac{\mathscr{\Xi}}{\stackrel{\Xi}{\pi}}$ & $\frac{0}{\frac{0}{0.00}}$ & 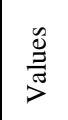 \\
\hline \multirow{4}{*}{ 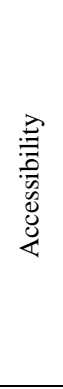 } & $\begin{array}{c}\text { Possibility of receiving } \\
\text { products at home }\end{array}$ & I & 0.01 & 6.61 & 0.1 & 2 & 0.08 & 2.06 & 0.06 & 2.03 & 0.04 & 3.23 & 0.03 & 5.74 & 0.08 & 4.59 \\
\hline & Absence of lines & I & 0.05 & 2.76 & 0.03 & 8.94 & 0.03 & 8.09 & 0.08 & 8.24 & 0.08 & 4.13 & 0.02 & 7.69 & 0.01 & 7.54 \\
\hline & $\begin{array}{l}\text { Absence of the } \\
\text { necessity for special } \\
\text { equipment and skills }\end{array}$ & $\mathrm{T}$ & 0.06 & 2.93 & 0.09 & 3.31 & 0.08 & 6.33 & 0.02 & 2.46 & 0.06 & 7.59 & 0.06 & 2.87 & 0.1 & 8.49 \\
\hline & $\begin{array}{l}\text { Stability, reliability, } \\
\text { and security (absence } \\
\text { of interruptions in } \\
\text { products supply) }\end{array}$ & $\mathrm{T}$ & 0.02 & 1.53 & 0.06 & 9.03 & 0.04 & 8.66 & 0.04 & 7.12 & 0.09 & 1.89 & 0.06 & 5.45 & 0.07 & 1.25 \\
\hline \multirow{2}{*}{ 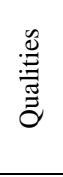 } & $\begin{array}{l}\text { Stability of the process } \\
\text { of purchase and usage } \\
\text { of products }\end{array}$ & $\mathrm{T}$ & 0.03 & 8.39 & 0.07 & 4.95 & 0.05 & 3.59 & 0.01 & 5.07 & 0.03 & 3.31 & 0.03 & 5 & 0.03 & 9.38 \\
\hline & $\begin{array}{l}\text { Modern nature of } \\
\text { products }\end{array}$ & I & 0.24 & 6.49 & 0.06 & 2.04 & 0.12 & 1.8 & 0.16 & 5.61 & 0.12 & 7.5 & 0.1 & 4.95 & 0.05 & 9.47 \\
\hline \multirow{3}{*}{ 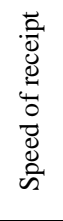 } & $\begin{array}{c}\text { Possibility of obtaining } \\
\text { products at once }\end{array}$ & $\mathrm{T}$ & 0.01 & 2.12 & 0.1 & 2.06 & 0.07 & 5.45 & 0.02 & 7.28 & 0.1 & 2.93 & 0.07 & 6.74 & 0.08 & 2.74 \\
\hline & $\begin{array}{l}\text { Personal contact with } \\
\text { supplier of products }\end{array}$ & $\mathrm{T}$ & 0.07 & 8.31 & 0.02 & 6.56 & 0.05 & 3.85 & 0.05 & 5.75 & 0.04 & 1.99 & 0.06 & 7.34 & 0.1 & 9.23 \\
\hline & $\begin{array}{l}\text { Possibility of applying } \\
\text { for products any time }\end{array}$ & I & 0.08 & 6.41 & 0.09 & 4.33 & 0.09 & 4.88 & 0.02 & 9.82 & 0.02 & 9.83 & 0.09 & 2.2 & 0.06 & 9.72 \\
\hline \multirow{2}{*}{ 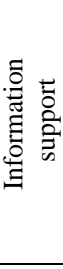 } & $\begin{array}{c}\text { Simplicity of selection } \\
\text { of the necessary } \\
\text { products }\end{array}$ & $\mathrm{T}$ & 0.08 & 3.15 & 0.03 & 8.63 & 0.08 & 2.01 & 0.09 & 2.26 & 0.03 & 1.2 & 0.04 & 2.48 & 0.05 & 8.23 \\
\hline & $\begin{array}{c}\text { Informing on the } \\
\text { process of manufacture } \\
\text { and shipment of } \\
\text { product (provision of } \\
\text { service) } \\
\end{array}$ & I & 0.06 & 8.1 & 0.03 & 5.62 & 0.01 & 1.77 & 0.1 & 5.18 & 0.03 & 5.08 & 0.09 & 3.83 & 0.1 & 4.82 \\
\hline \multirow{2}{*}{ : } & $\begin{array}{l}\text { Individualization of } \\
\text { products }\end{array}$ & I & 0.17 & 8.52 & 0.13 & 3.54 & 0.16 & 5.36 & 0.19 & 8.91 & 0.15 & 6.7 & 0.2 & 4.28 & 0.06 & 9.83 \\
\hline & $\begin{array}{c}\text { Value of personal } \\
\text { relations with products } \\
\text { supplier } \\
\end{array}$ & $\mathrm{T}$ & 0.05 & 3.41 & 0.06 & 2.86 & 0.05 & 8.29 & 0.03 & 3.05 & 0.03 & 1.01 & 0.05 & 4.82 & 0.04 & 8.48 \\
\hline \multirow{2}{*}{ 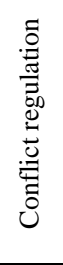 } & $\begin{array}{c}\text { Simplicity of feedback } \\
\text { (reviews, complaints, } \\
\text { and offers) }\end{array}$ & I & 0.02 & 2.44 & 0.08 & 8.57 & 0.05 & 3.24 & 0.05 & 3.89 & 0.08 & 8.79 & 0.06 & 9.29 & 0.08 & 5.79 \\
\hline & $\begin{array}{c}\text { Simplicity and speed of } \\
\text { protection and sales } \\
\text { legal rights for return } \\
\text { and exchange of } \\
\text { products } \\
\end{array}$ & $\mathrm{T}$ & 0.05 & 2.45 & 0.05 & 9.59 & 0.04 & 8.05 & 0.08 & 3.97 & 0.1 & 2.69 & 0.04 & 1.4 & 0.09 & 7.28 \\
\hline
\end{tabular}

Source: data obtained by the author, the table developed and compiled by the author. 
Table 3. Significance of traditions and innovations and perceived quality of state services in top7 regions of Russia as to the level of development of the knowledge economy in 2019

\begin{tabular}{|c|c|c|c|c|c|c|c|c|c|c|c|c|c|c|c|c|}
\hline \multirow{2}{*}{ 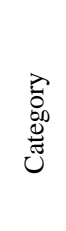 } & \multirow[b]{2}{*}{ Indicators } & \multirow[b]{2}{*}{ Type } & \multicolumn{2}{|c|}{$\begin{array}{l}\text { Republic } \\
\text { of } \\
\text { Tatarstan }\end{array}$} & \multicolumn{2}{|c|}{$\begin{array}{l}\text { Tomsk } \\
\text { Oblast }\end{array}$} & \multicolumn{2}{|c|}{$\begin{array}{c}\text { Moscow } \\
\text { Oblast }\end{array}$} & \multicolumn{2}{|c|}{$\begin{array}{c}\text { Novosibirsk } \\
\text { Oblast }\end{array}$} & \multicolumn{2}{|c|}{$\begin{array}{l}\text { Kaluga } \\
\text { Oblast }\end{array}$} & \multicolumn{2}{|c|}{$\begin{array}{c}\text { Nizhny } \\
\text { Novgorod } \\
\text { Oblast } \\
\end{array}$} & \multicolumn{2}{|c|}{$\begin{array}{c}\text { Ulyanovsk } \\
\text { Oblast }\end{array}$} \\
\hline & & & $\frac{0}{3}$ & $\frac{0}{\stackrel{0}{\pi}}$ & $\frac{0}{0}$ & $\stackrel{\mathscr{\Xi}}{\stackrel{\Xi}{\sigma}}$ & $\frac{0}{3}$ & 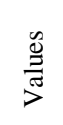 & $\frac{0}{\frac{0}{6}}$ & $\frac{\tilde{\Xi}}{\tilde{\sigma}}$ & $\begin{array}{l}0 \\
\frac{0}{600} \\
3 \\
3\end{array}$ & 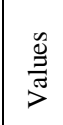 & $\frac{0}{0.0}$ & $\frac{\tilde{\Xi}}{\tilde{\Xi}}$ & $\frac{2}{\frac{00}{20}}$ & 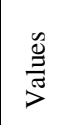 \\
\hline \multirow{4}{*}{ 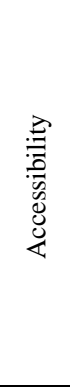 } & $\begin{array}{c}\text { Possibility of receiving } \\
\text { products at home }\end{array}$ & I & 0.03 & 7.98 & 0.02 & 3.41 & 0.08 & 6.47 & 0.05 & 5.16 & 0.08 & 1.61 & 0.09 & 5.59 & 0.06 & 3.68 \\
\hline & Absence of lines & I & 0.12 & 9.53 & 0.2 & 1.13 & 0.1 & 4.64 & 0.14 & 4.44 & 0.17 & 1.85 & 0.08 & 1.63 & 0.11 & 6.25 \\
\hline & $\begin{array}{c}\text { Absence of the } \\
\text { necessity for special } \\
\text { equipment and skills }\end{array}$ & $\mathrm{T}$ & 0.1 & 1.26 & 0.03 & 5.27 & 0.04 & 9.24 & 0.06 & 1.8 & 0.03 & 1.79 & 0.07 & 9.64 & 0.08 & 2.25 \\
\hline & $\begin{array}{l}\text { Stability, reliability, } \\
\text { and security (absence } \\
\text { of interruptions in } \\
\text { products supply) }\end{array}$ & $\mathrm{T}$ & 0.07 & 4.54 & 0.08 & 9.88 & 0.07 & 5.64 & 0.05 & 7.69 & 0.03 & 9.05 & 0.1 & 9.54 & 0.05 & 6.85 \\
\hline \multirow{2}{*}{$\frac{\stackrel{0}{\Xi}}{\stackrel{\widetilde{\Xi}}{\Xi}}$} & $\begin{array}{c}\text { Stability of the process } \\
\text { of purchase and usage } \\
\text { of products }\end{array}$ & $\mathrm{T}$ & 0.07 & 6.33 & 0.06 & 6.1 & 0.08 & 7.43 & 0.02 & 1.22 & 0.04 & 5.5 & 0.07 & 5.15 & 0.02 & 2.65 \\
\hline & $\begin{array}{c}\text { Modern nature of } \\
\text { products }\end{array}$ & I & 0.08 & 9.61 & 0.04 & 8.52 & 0.03 & 3.71 & 0.09 & 3.38 & 0.05 & 9.59 & 0.01 & 3.41 & 0.04 & 9.95 \\
\hline \multirow{3}{*}{ 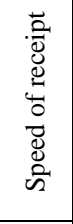 } & $\begin{array}{c}\text { Possibility of obtaining } \\
\text { products at once }\end{array}$ & $\mathrm{T}$ & 0.05 & 9.7 & 0.08 & 6.64 & 0.1 & 1.19 & 0.01 & 5.91 & 0.03 & 9.14 & 0.08 & 7.43 & 0.06 & 3.89 \\
\hline & $\begin{array}{l}\text { Personal contact with } \\
\text { supplier of products }\end{array}$ & $\mathrm{T}$ & 0.02 & 1.85 & 0.02 & 9.58 & 0.1 & 9.25 & 0.09 & 8.04 & 0.05 & 6.47 & 0.08 & 5.76 & 0.08 & 6.47 \\
\hline & $\begin{array}{l}\text { Possibility of applying } \\
\text { for products any time }\end{array}$ & I & 0.1 & 5.24 & 0.15 & 1.11 & 0.08 & 3.81 & 0.11 & 8.03 & 0.17 & 1.29 & 0.08 & 7.21 & 0.12 & 8.5 \\
\hline \multirow{2}{*}{ 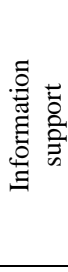 } & $\begin{array}{c}\text { Simplicity of selection } \\
\text { of the necessary } \\
\text { products }\end{array}$ & $\mathrm{T}$ & 0.1 & 3.39 & 0.05 & 9.87 & 0.02 & 1.78 & 0.07 & 4.27 & 0.02 & 5.63 & 0.04 & 1.8 & 0.08 & 8.16 \\
\hline & $\begin{array}{l}\text { Informing on the } \\
\text { process of manufacture } \\
\text { and shipment of } \\
\text { product (provision of } \\
\text { service) }\end{array}$ & I & 0.03 & 7.65 & 0.02 & 4.33 & 0.09 & 3.86 & 0.07 & 4.06 & 0.05 & 3.61 & 0.05 & 7.88 & 0.07 & 2.98 \\
\hline \multirow{2}{*}{ 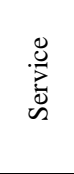 } & $\begin{array}{l}\text { Individualization of } \\
\text { products }\end{array}$ & I & 0.05 & 1.6 & 0.04 & 9.36 & 0.02 & 6.05 & 0.03 & 4.82 & 0.04 & 1.72 & 0.09 & 5.08 & 0.03 & 4.76 \\
\hline & $\begin{array}{c}\text { Value of personal } \\
\text { relations with products } \\
\text { supplier }\end{array}$ & $\mathrm{T}$ & 0.08 & 7.29 & 0.02 & 6.54 & 0.07 & 4.49 & 0.03 & 4.53 & 0.02 & 7.29 & 0.06 & 9.29 & 0.05 & 7.71 \\
\hline \multirow{2}{*}{ 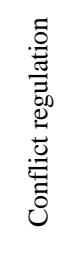 } & $\begin{array}{c}\text { Simplicity of feedback } \\
\text { (reviews, complaints, } \\
\text { and offers) }\end{array}$ & I & 0.08 & 7.09 & 0.16 & 2.01 & 0.1 & 6.74 & 0.09 & 5.62 & 0.13 & 7.6 & 0.09 & 1.15 & 0.13 & 4.75 \\
\hline & \begin{tabular}{|c|} 
Simplicity and speed of \\
protection and sales \\
legal rights for return \\
and exchange of \\
products
\end{tabular} & $\mathrm{T}$ & 0.02 & 1.19 & 0.03 & 7.28 & 0.02 & 5.02 & 0.09 & 3.37 & 0.09 & 2.63 & 0.01 & 6 & 0.02 & 4.85 \\
\hline
\end{tabular}

Source: data obtained by the author, the table developed and compiled by the author. 
Table 4. Significance of traditions and innovations and perceived quality of retail trade products in top-7 regions of Russia as to the level of development of the knowledge economy in 2015

\begin{tabular}{|c|c|c|c|c|c|c|c|c|c|c|c|c|c|c|c|c|}
\hline \multirow{2}{*}{ 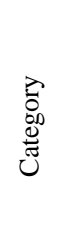 } & \multirow[b]{2}{*}{ Indicators } & \multirow[b]{2}{*}{ Type } & \multicolumn{2}{|c|}{$\begin{array}{l}\text { Republic } \\
\text { of } \\
\text { Tatarstan }\end{array}$} & \multicolumn{2}{|c|}{$\begin{array}{l}\text { Tomsk } \\
\text { Oblast }\end{array}$} & \multicolumn{2}{|c|}{$\begin{array}{c}\text { Moscow } \\
\text { Oblast }\end{array}$} & \multicolumn{2}{|c|}{$\begin{array}{c}\text { Novosibirsk } \\
\text { Oblast }\end{array}$} & \multicolumn{2}{|c|}{$\begin{array}{l}\text { Kaluga } \\
\text { Oblast }\end{array}$} & \multicolumn{2}{|c|}{\begin{tabular}{|c|} 
Nizhny \\
Novgorod \\
Oblast \\
\end{tabular}} & \multicolumn{2}{|c|}{$\begin{array}{c}\text { Ulyanovsk } \\
\text { Oblast }\end{array}$} \\
\hline & & & $\begin{array}{l}\frac{0}{0} \\
\frac{50}{0} \\
3\end{array}$ & $\frac{0}{\stackrel{0}{\pi}}$ & $\begin{array}{l}\frac{0}{0} \\
\frac{.00}{0} \\
3\end{array}$ & 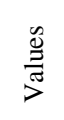 & $\begin{array}{l}0 \\
\frac{0}{0.0} \\
\frac{.00}{3} \\
3\end{array}$ & $\frac{0}{\stackrel{0}{\sigma}}$ & $\frac{0}{0}$ & 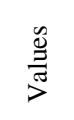 & $\begin{array}{l}0 \\
\frac{0}{000} \\
\frac{.00}{3}\end{array}$ & $\frac{\mathscr{0}}{\stackrel{0}{\pi}}$ & $\begin{array}{l}0 \\
\frac{0}{0} \\
\frac{.00}{0} \\
3\end{array}$ & 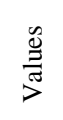 & $\begin{array}{l}0 \\
\frac{0}{60} \\
\frac{.00}{2} \\
3\end{array}$ & 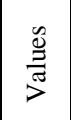 \\
\hline \multirow{4}{*}{ 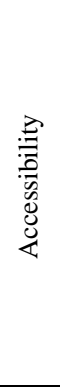 } & $\begin{array}{l}\text { Possibility of receiving } \\
\text { products at home }\end{array}$ & I & 0.13 & 6.14 & 0.07 & 7.95 & 0.09 & 8.67 & 0.23 & 1.62 & 0.11 & 4.13 & 0.23 & 3.38 & 0.11 & 6,64 \\
\hline & Absence of lines & I & 0.16 & 2.91 & 0.09 & 3.44 & 0.07 & 1.74 & 0.17 & 6.98 & 0.16 & 6.62 & 0.17 & 2.3 & 0.1 & 9,66 \\
\hline & $\begin{array}{l}\text { Absence of the } \\
\text { necessity for special } \\
\text { equipment and skills }\end{array}$ & $\mathrm{T}$ & 0.1 & 6.42 & 0.06 & 2.71 & 0.09 & 7.15 & 0.03 & 9.09 & 0.02 & 5.44 & 0.04 & 2.62 & 0.04 & 7,56 \\
\hline & $\begin{array}{l}\text { Stability, reliability, } \\
\text { and security (absence } \\
\text { of interruptions in } \\
\text { products supply) }\end{array}$ & $\mathrm{T}$ & 0.06 & 8.09 & 0.03 & 9.21 & 0.04 & 4.19 & 0.07 & 1.34 & 0.09 & 6.66 & 0.02 & 1.37 & 0.09 & 8,71 \\
\hline \multirow{2}{*}{ 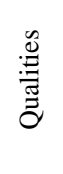 } & $\begin{array}{c}\text { Stability of the process } \\
\text { of purchase and usage } \\
\text { of products }\end{array}$ & $\mathrm{T}$ & 0.03 & 2.48 & 0.07 & 4.62 & 0.08 & 7.86 & 0.05 & 6.78 & 0.06 & 8.72 & 0.04 & 4.42 & 0.02 & 3,8 \\
\hline & $\begin{array}{l}\text { Modern nature of } \\
\text { products }\end{array}$ & I & 0.02 & 1.83 & 0.06 & 6.17 & 0.02 & 3.92 & 0.09 & 7.3 & 0.05 & 5.21 & 0.01 & 7.2 & 0.07 & 1,2 \\
\hline \multirow{3}{*}{ 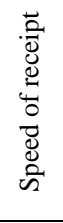 } & $\begin{array}{c}\text { Possibility of obtaining } \\
\text { products at once }\end{array}$ & $\mathrm{T}$ & 0.09 & 5.14 & 0.05 & 3.62 & 0.1 & 9.95 & 0.01 & 1.66 & 0.05 & 3.38 & 0.07 & 5.89 & 0.05 & 8,68 \\
\hline & $\begin{array}{l}\text { Personal contact with } \\
\text { supplier of products }\end{array}$ & $\mathrm{T}$ & 0.04 & 2.24 & 0.09 & 9.43 & 0.03 & 7.16 & 0.02 & 2.37 & 0.04 & 1.1 & 0.03 & 1.68 & 0.06 & 7,61 \\
\hline & $\begin{array}{l}\text { Possibility of applying } \\
\text { for products any time }\end{array}$ & I & 0.05 & 9.43 & 0.08 & 6.45 & 0.07 & 7.05 & 0.03 & 6.37 & 0.06 & 3.29 & 0.04 & 9.36 & 0.05 & 1,38 \\
\hline \multirow{2}{*}{ 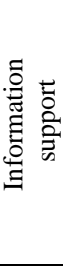 } & $\begin{array}{c}\text { Simplicity of selection } \\
\text { of the necessary } \\
\text { products }\end{array}$ & $\mathrm{T}$ & 0.01 & 2.79 & 0.04 & 7.96 & 0.09 & 6.35 & 0.03 & 2.11 & 0.02 & 4.32 & 0.08 & 3.34 & 0.08 & 8,5 \\
\hline & $\begin{array}{l}\text { Informing on the } \\
\text { process of manufacture } \\
\text { and shipment of } \\
\text { product (provision of } \\
\text { service) } \\
\end{array}$ & I & 0.05 & 5.12 & 0.05 & 8.02 & 0.09 & 1.1 & 0.05 & 1.42 & 0.1 & 9.63 & 0.07 & 3.44 & 0.08 & 3,27 \\
\hline \multirow{2}{*}{ 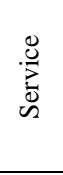 } & $\begin{array}{l}\text { Individualization of } \\
\text { products }\end{array}$ & I & 0.1 & 8.78 & 0.08 & 1.07 & 0.07 & 9 & 0.05 & 1.68 & 0.07 & 9.15 & 0.06 & 8.25 & 0.04 & 3,18 \\
\hline & $\begin{array}{l}\text { Value of personal } \\
\text { relations with products } \\
\text { supplier }\end{array}$ & $\mathrm{T}$ & 0.03 & 3.89 & 0.09 & 9.14 & 0.01 & 6.66 & 0.08 & 9.43 & 0.09 & 3.52 & 0.09 & 6.7 & 0.11 & 4,69 \\
\hline \multirow{2}{*}{ 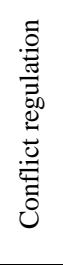 } & $\begin{array}{c}\text { Simplicity of feedback } \\
\text { (reviews, complaints, } \\
\text { and offers) }\end{array}$ & I & 0.06 & 3.85 & 0.07 & 2.65 & 0.07 & 8.61 & 0.01 & 8.5 & 0.01 & 4.44 & 0.03 & 1.04 & 0.06 & 8,3 \\
\hline & $\begin{array}{l}\text { Simplicity and speed of } \\
\text { protection and sales } \\
\text { legal rights for return } \\
\text { and exchange of } \\
\text { products }\end{array}$ & $\mathrm{T}$ & 0.07 & 5.38 & 0.07 & 1.86 & 0.08 & 3.01 & 0.08 & 5.95 & 0.07 & 6.31 & 0.02 & 3.61 & 0.04 & 6,99 \\
\hline
\end{tabular}

Source: data obtained by the author, the table developed and compiled by the author 
Table 5. Significance of traditions and innovations and perceived quality of hi-tech products in top-7 regions of Russia as to the level of development of the knowledge economy in 2015

\begin{tabular}{|c|c|c|c|c|c|c|c|c|c|c|c|c|c|c|c|c|}
\hline \multirow{2}{*}{ 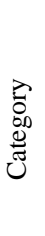 } & \multirow[b]{2}{*}{ Indicators } & \multirow[b]{2}{*}{ Type } & \multicolumn{2}{|c|}{$\begin{array}{l}\text { Republic } \\
\text { of } \\
\text { Tatarstan }\end{array}$} & \multicolumn{2}{|c|}{$\begin{array}{l}\text { Tomsk } \\
\text { Oblast }\end{array}$} & \multicolumn{2}{|c|}{$\begin{array}{c}\text { Moscow } \\
\text { Oblast }\end{array}$} & \multicolumn{2}{|c|}{$\begin{array}{c}\text { Novosibirsk } \\
\text { Oblast }\end{array}$} & \multicolumn{2}{|c|}{$\begin{array}{l}\text { Kaluga } \\
\text { Oblast }\end{array}$} & \multicolumn{2}{|c|}{$\begin{array}{c}\text { Nizhny } \\
\text { Novgorod } \\
\text { Oblast }\end{array}$} & \multicolumn{2}{|c|}{$\begin{array}{l}\text { Ulyanovsk } \\
\text { Oblast }\end{array}$} \\
\hline & & & 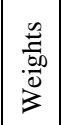 & 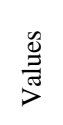 & $\begin{array}{l}0 \\
\frac{0}{00} \\
\frac{.00}{0} \\
3\end{array}$ & 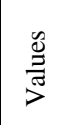 & $\begin{array}{l}\frac{0}{20} \\
\frac{00}{0} \\
3\end{array}$ & 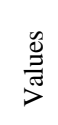 & 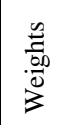 & $\frac{\mathscr{\varrho}}{\stackrel{n}{\pi}}$ & $\begin{array}{l}0 \\
\frac{0}{0} \\
\frac{.00}{0} \\
3\end{array}$ & $\frac{\mathscr{\varrho}}{\pi}$ & $\begin{array}{l}\frac{\infty}{0} \\
\frac{000}{20} \\
3\end{array}$ & $\frac{0}{\stackrel{0}{\sigma}}$ & $\begin{array}{l}0 \\
\frac{0}{0.0} \\
\frac{.00}{2} \\
3\end{array}$ & 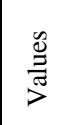 \\
\hline \multirow{4}{*}{ 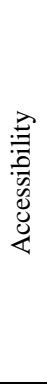 } & $\begin{array}{c}\text { Possibility of receiving } \\
\text { products at home }\end{array}$ & I & 0.01 & 6.51 & 0.1 & 1.96 & 0.08 & 1.97 & 0.06 & 1.94 & 0.04 & 3.2 & 0.03 & 5.7 & 0.08 & 4.54 \\
\hline & Absence of lines & I & 0.05 & 2.73 & 0.03 & 8.91 & 0.03 & 8.01 & 0.08 & 8.18 & 0.08 & 4.09 & 0.02 & 7.61 & 0.01 & 7.47 \\
\hline & $\begin{array}{c}\text { Absence of the } \\
\text { necessity for special } \\
\text { equipment and skills }\end{array}$ & $\mathrm{T}$ & 0.06 & 2.83 & 0.09 & 3.27 & 0.08 & 6.23 & 0.02 & 2.37 & 0.06 & 7.52 & 0.06 & 2.79 & 0.1 & 8.4 \\
\hline & $\begin{array}{l}\text { Stability, reliability, } \\
\text { and security (absence } \\
\text { of interruptions in } \\
\text { products supply) }\end{array}$ & $\mathrm{T}$ & 0.04 & 1.5 & 0.06 & 8.95 & 0.04 & 8.64 & 0.04 & 7.07 & 0.09 & 1.83 & 0.07 & 5.4 & 0.07 & 1.16 \\
\hline \multirow{2}{*}{$\frac{\mathscr{2}}{\stackrel{\Xi}{\Xi}}$} & $\begin{array}{c}\text { Stability of the process } \\
\text { of purchase and usage } \\
\text { of products }\end{array}$ & $\mathrm{T}$ & 0.03 & 8.37 & 0.07 & 4.87 & 0.05 & 3.5 & 0.05 & 4.98 & 0.03 & 3.22 & 0.03 & 4.98 & 0.03 & 9.32 \\
\hline & $\begin{array}{l}\text { Modern nature of } \\
\text { products }\end{array}$ & I & 0.23 & 6.46 & 0.06 & 2.01 & 0.11 & 1.71 & 0.16 & 5.53 & 0.12 & 7.44 & 0.09 & 4.9 & 0.05 & 9.43 \\
\hline \multirow{3}{*}{ 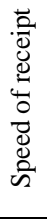 } & $\begin{array}{c}\text { Possibility of obtaining } \\
\text { products at once }\end{array}$ & $\mathrm{T}$ & 0.01 & 2.06 & 0.1 & 2.04 & 0.07 & 5.42 & 0.02 & 7.23 & 0.1 & 2.86 & 0.07 & 6.68 & 0.08 & 2.65 \\
\hline & $\begin{array}{l}\text { Personal contact with } \\
\text { supplier of products }\end{array}$ & $\mathrm{T}$ & 0.07 & 8.3 & 0.02 & 6.48 & 0.06 & 3.78 & 0.05 & 5.74 & 0.04 & 1.96 & 0.06 & 7.26 & 0.1 & 9.21 \\
\hline & $\begin{array}{l}\text { Possibility of applying } \\
\text { for products any time }\end{array}$ & I & 0.08 & 6.33 & 0.09 & 4.3 & 0.1 & 4.85 & 0.04 & 9.79 & 0.02 & 9.8 & 0.09 & 2.13 & 0.06 & 9.64 \\
\hline \multirow{2}{*}{ 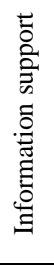 } & $\begin{array}{c}\text { Simplicity of selection } \\
\text { of the necessary } \\
\text { products }\end{array}$ & $\mathrm{T}$ & 0.08 & 3.07 & 0.03 & 8.56 & 0.08 & 1.93 & 0.09 & 2.23 & 0.03 & 1.16 & 0.04 & 2.45 & 0.05 & 8.18 \\
\hline & $\begin{array}{l}\text { Informing on the } \\
\text { process of manufacture } \\
\text { and shipment of } \\
\text { product (provision of } \\
\text { service) }\end{array}$ & I & 0.06 & 8.06 & 0.03 & 5.58 & 0.01 & 1.74 & 0.05 & 5.12 & 0.03 & 5.05 & 0.09 & 3.8 & 0.1 & 4.78 \\
\hline \multirow{2}{*}{ 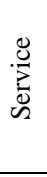 } & $\begin{array}{l}\text { Individualization of } \\
\text { products }\end{array}$ & I & 0.16 & 8.45 & 0.12 & 3.45 & 0.15 & 5.3 & 0.18 & 8.89 & 0.14 & 6.68 & 0.2 & 4.21 & 0.06 & 9.81 \\
\hline & $\begin{array}{l}\text { Value of personal } \\
\text { relations with products } \\
\text { supplier }\end{array}$ & $\mathrm{T}$ & 0.05 & 3.36 & 0.06 & 2.83 & 0.05 & 8.2 & 0.03 & 2.98 & 0.03 & 0.92 & 0.05 & 4.73 & 0.04 & 8.39 \\
\hline \multirow{2}{*}{ 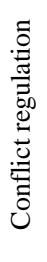 } & $\begin{array}{l}\text { Simplicity of feedback } \\
\text { (reviews, complaints, } \\
\text { and offers) }\end{array}$ & I & 0.02 & 2.35 & 0.09 & 8.54 & 0.05 & 3.18 & 0.05 & 3.83 & 0.09 & 8.72 & 0.06 & 9.19 & 0.08 & 5.77 \\
\hline & $\begin{array}{l}\text { Simplicity and speed of } \\
\text { protection and sales } \\
\text { legal rights for return } \\
\text { and exchange of } \\
\text { products }\end{array}$ & $\mathrm{T}$ & 0.05 & 2.39 & 0.05 & 9.52 & 0.04 & 8.02 & 0.08 & 3.94 & 0.1 & 2.61 & 0.04 & 1.31 & 0.09 & 7.25 \\
\hline
\end{tabular}

Source: data obtained by the author, the table developed and compiled by the author 
Table 6. Significance of traditions and innovations and perceived quality of state services in top7 regions of Russia as to the level of development of the knowledge economy in 2015

\begin{tabular}{|c|c|c|c|c|c|c|c|c|c|c|c|c|c|c|c|c|}
\hline \multirow{2}{*}{ 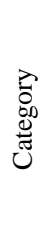 } & \multirow[b]{2}{*}{ Indicators } & \multirow[b]{2}{*}{ Type } & \multicolumn{2}{|c|}{$\begin{array}{l}\text { Republic } \\
\text { of } \\
\text { Tatarstan }\end{array}$} & \multicolumn{2}{|c|}{$\begin{array}{l}\text { Tomsk } \\
\text { Oblast }\end{array}$} & \multicolumn{2}{|c|}{$\begin{array}{c}\text { Moscow } \\
\text { Oblast }\end{array}$} & \multicolumn{2}{|c|}{$\begin{array}{l}\text { Novosibirsk } \\
\text { Oblast }\end{array}$} & \multicolumn{2}{|c|}{$\begin{array}{l}\text { Kaluga } \\
\text { Oblast }\end{array}$} & \multicolumn{2}{|c|}{$\begin{array}{c}\text { Nizhny } \\
\text { Novgorod } \\
\text { Oblast } \\
\end{array}$} & \multicolumn{2}{|c|}{$\begin{array}{c}\text { Ulyanovsk } \\
\text { Oblast }\end{array}$} \\
\hline & & & $\begin{array}{l}\frac{0}{0} \\
\frac{0}{00} \\
\frac{1}{3}\end{array}$ & $\frac{\ddot{g}}{\tilde{\sigma}}$ & $\begin{array}{l}\frac{n}{0} \\
\frac{00}{00} \\
3\end{array}$ & $\frac{\varrho}{\stackrel{0}{\pi}}$ & $\begin{array}{l}0 \\
\frac{0}{00} \\
\frac{00}{0} \\
3\end{array}$ & $\frac{\tilde{g}}{\tilde{\sigma}}$ & $\begin{array}{l}\frac{0}{2} \\
\frac{00}{2} \\
3\end{array}$ & $\underset{\stackrel{0}{\Xi}}{\stackrel{\tilde{\sigma}}{\sigma}}$ & $\begin{array}{l}\frac{0}{2} \\
\frac{000}{00} \\
3\end{array}$ & $\frac{\mathscr{v}}{\tilde{\sigma}}$ & $\frac{0}{\frac{0}{60}}$ & $\frac{\mathscr{e}}{\stackrel{\Xi}{\sigma}}$ & $\begin{array}{l}0 \\
\frac{0}{600} \\
\frac{0}{2} \\
3\end{array}$ & $\frac{\ddot{\Xi}}{\stackrel{\tilde{\sigma}}{\nu}}$ \\
\hline \multirow{4}{*}{ 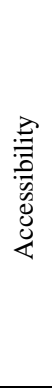 } & $\begin{array}{c}\text { Possibility of receiving } \\
\text { products at home }\end{array}$ & I & 0.03 & 7.92 & 0.02 & 3.37 & 0.08 & 6.4 & 0.06 & 5.11 & 0.08 & 1.55 & 0.09 & 5.56 & 0.06 & 3.6 \\
\hline & Absence of lines & I & 0.12 & 9.45 & 0.19 & 1.1 & 0.09 & 4.55 & 0.14 & 4.36 & 0.16 & 1.79 & 0.08 & 1.58 & 0.09 & 6.22 \\
\hline & $\begin{array}{l}\text { Absence of the } \\
\text { necessity for special } \\
\text { equipment and skills }\end{array}$ & $\mathrm{T}$ & 0.1 & 1.21 & 0.03 & 5.23 & 0.04 & 9.2 & 0.06 & 1.72 & 0.03 & 1.77 & 0.07 & 9.59 & 0.08 & 2.17 \\
\hline & $\begin{array}{l}\text { Stability, reliability, } \\
\text { and security (absence } \\
\text { of interruptions in } \\
\text { products supply) }\end{array}$ & $\mathrm{T}$ & 0.07 & 4.52 & 0.08 & 9.81 & 0.07 & 5.63 & 0.05 & 7.62 & 0.03 & 9 & 0.1 & 9.47 & 0.05 & 6.76 \\
\hline \multirow{2}{*}{$\frac{\mathscr{0}}{:}$} & $\begin{array}{c}\text { Stability of the process } \\
\text { of purchase and usage } \\
\text { of products }\end{array}$ & $\mathrm{T}$ & 0.07 & 6.25 & 0.06 & 6.06 & 0.08 & 7.36 & 0.02 & 1.19 & 0.04 & 5.41 & 0.07 & 5.07 & 0.02 & 2.61 \\
\hline & $\begin{array}{l}\text { Modern nature of } \\
\text { products }\end{array}$ & I & 0.08 & 9.52 & 0.04 & 8.43 & 0.03 & 3.66 & 0.09 & 3.29 & 0.05 & 9.54 & 0.01 & 3.35 & 0.05 & 9.87 \\
\hline \multirow{3}{*}{ 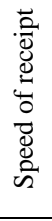 } & $\begin{array}{l}\text { Possibility of obtaining } \\
\text { products at once }\end{array}$ & $\mathrm{T}$ & 0.05 & 9.61 & 0.08 & 6.63 & 0.1 & 1.1 & 0.01 & 5.83 & 0.04 & 9.04 & 0.08 & 7.39 & 0.06 & 3.86 \\
\hline & $\begin{array}{l}\text { Personal contact with } \\
\text { supplier of products }\end{array}$ & $\mathrm{T}$ & 0.02 & 1.83 & 0.02 & 9.5 & 0.09 & 9.16 & 0.09 & 7.98 & 0.05 & 6.38 & 0.08 & 5.7 & 0.08 & 6.41 \\
\hline & $\begin{array}{l}\text { Possibility of applying } \\
\text { for products any time }\end{array}$ & I & 0.1 & 5.17 & 0.15 & 1.07 & 0.05 & 3.75 & 0.11 & 7.95 & 0.17 & 1.22 & 0.08 & 7.17 & 0.11 & 8.42 \\
\hline \multirow{2}{*}{ 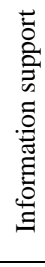 } & $\begin{array}{c}\text { Simplicity of selection } \\
\text { of the necessary } \\
\text { products }\end{array}$ & $\mathrm{T}$ & 0.11 & 3.29 & 0.06 & 9.83 & 0.07 & 1.7 & 0.07 & 4.19 & 0.02 & 5.54 & 0.04 & 1.78 & 0.08 & 8.13 \\
\hline & $\begin{array}{l}\text { Informing on the } \\
\text { process of manufacture } \\
\text { and shipment of } \\
\text { product (provision of } \\
\text { service) }\end{array}$ & I & 0.03 & 7.61 & 0.02 & 4.32 & 0.09 & 3.8 & 0.07 & 3.99 & 0.05 & 3.59 & 0.05 & 7.84 & 0.07 & 2.9 \\
\hline \multirow{2}{*}{ 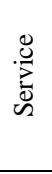 } & $\begin{array}{l}\text { Individualization of } \\
\text { products }\end{array}$ & I & 0.05 & 1.54 & 0.04 & 9.29 & 0.02 & 6.04 & 0.03 & 4.79 & 0.04 & 1.63 & 0.09 & 5.05 & 0.03 & 4.68 \\
\hline & $\begin{array}{l}\text { Value of personal } \\
\text { relations with products } \\
\text { supplier }\end{array}$ & $\mathrm{T}$ & 0.08 & 7.27 & 0.02 & 6.53 & 0.07 & 4.39 & 0.03 & 4.5 & 0.02 & 7.2 & 0.06 & 9.24 & 0.05 & 7.62 \\
\hline \multirow{2}{*}{ 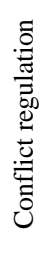 } & $\begin{array}{c}\text { Simplicity of feedback } \\
\text { (reviews, complaints, } \\
\text { and offers) }\end{array}$ & I & 0.07 & 7.06 & 0.16 & 1.93 & 0.1 & 6.68 & 0.08 & 5.56 & 0.13 & 7.54 & 0.09 & 1.05 & 0.13 & 4.7 \\
\hline & $\begin{array}{l}\text { Simplicity and speed of } \\
\text { protection and sales } \\
\text { legal rights for return } \\
\text { and exchange of } \\
\text { products }\end{array}$ & $\mathrm{T}$ & 0.02 & 1.09 & 0.03 & 7.23 & 0.02 & 4.99 & 0.09 & 3.28 & 0.09 & 2.61 & 0.01 & 5.99 & 0.04 & 4.79 \\
\hline
\end{tabular}

Source: data obtained by the author, the table developed and compiled by the author 
QUALITY International Journal for Quality Research 